\title{
The Effect Of Changes In Price Level, Product Quality, Quality Of Service On Purchase Decisions In Ud. Ghoni Jati Jaya
}

\author{
Laili Nurrochmah ${ }^{1}$, Nur Tasya ${ }^{2}$, Noor Iffatin Nadhifah ${ }^{3 *}$, Sumarni $^{4}$ \\ 1,2 Student Of Management, Faculty Of Economics, \\ Permata Islamic Economics College Bojonegoro Jawa Timur Indonesia. \\ ${ }^{3,4}$ Departement Of Management, Faculty Of Economics, \\ Permata Islamic Economics College Bojonegoro Jawa Timur Indonesia. \\ ${ }^{*}$ Corresponding author: \\ Email: nadanadhiva1@gmail.com
}

\begin{abstract}
.
This study was to determine the effect of changes in price levels, product quality, and service quality affect purchasing decisions at UD. Ghoni Jati Jaya, and to find out which variables have the most influence on purchasing decisions. This research is quantitative. Researchers will describe the situation in the field and how consumers make purchasing decisions. The population in this study are all people who make purchases at UD. Ghoni Jati Jaya. The sample in this study used incidental random sampling method. To determine the size of the sample that will be used in this study, the slovin approach formula is used with a sample of 30 respondents because consumers are UD. Ghoni Jati Jaya is predicted to take 350 per year from 2014 to 2020. The analytical tool used is the research instrument test, namely the multiple regression linear test and assisted by SPSS. In this study, attempts to analyze the independent variable $(X)$ in this case is the independent variable that influences purchasing decisions, the independent variables include the price variable, product quality variable, and service quality variable. After everything is fulfilled, the last step is to do a multiple regression linear test. Variables of changes in price level, product quality, service quality are equal to zero or unchanged, then the $Y$ value or purchase decision is 8.815. or it can be said that the three variables including changes in price levels, product quality, service quality have a joint effect of about $88.1 \%$ on purchasing decisions. The results of the analysis that the variables of changes in price levels, product quality, and service quality have a significant effect on purchasing decisions at UD. Ghoni Jati Jaya
\end{abstract}

Keywords: Price, Quality Products, Quality Service, Purchase Decision

\section{INTRODUCTION}

Business development and rapid economic growth, as is currently becoming increasingly fierce competition in terms of existing businesses. Making companies increasingly demanded to move faster in terms of attracting consumers, so companies that apply marketing concepts need to pay close attention to consumer behavior and the factors that influence their purchasing decisions, in marketing efforts of a product. Every company or a form of business is competing to attract consumers to make purchasing decisions. In general, the purchase decision is the selection of two or more 
alternative choices. Some of the factors that influence purchasing decisions are prices, which are very influential and some are even the main benchmark in purchasing considerations.But the price can also be an indicator of the quality of a product. With high quality, they will dare to be pegged at a high price, the price can influence consumers in making decisions to buy a product. If the price refers to the quality of the product provided, as currently consumers are getting smarter in purchasing products. Some people who are so critical of a product's price and quality, tend to be the main consideration whether the product can provide benefits according to their needs and expectations more for them later. Then regarding service quality, the problems that are often faced are sometimes only providing services to consumers, such as without being there to attract and influence consumers to make purchasing decisions. So it's just a service but doesn't try to provide really quality service.

That is, good service even the best to influence and attract consumers to make purchasing decisions. Because the customer is like a king and even a king from any kingdom, he is still a king who basically must be served by really providing quality service.According to Philip Kotler (2007:223) purchasing decisions are several stages carried out by consumers before making a decision to purchase a product. Meanwhile, Kotler, Keller (2014: 184) further stated that the decision-making process is to purchase a product. Consumers usually start a five-stage model, namely: information seeking, evaluation, alternatives, purchase decisions and post-purchase behavior. Whether the product to be purchased is in accordance with his needs or desires. Then the product to be purchased is in accordance with his condition, such as the cost needed to get a desired product.Home industry scale entrepreneurs, small and medium industries in UD. Ghoni Jati Jaya. If the existing business actors cannot prepare themselves well to face the challenges of this competition, it is feared that their products will not be able to survive in the face of competition with other products, so that it will have an impact on their business continuity in the future. Based on this description, this research was conducted at UD. Ghoni Jati Jaya as one of the companies engaged in the sale of Jepara furniture.

\section{METHODS}

\section{Research Approach}

The approach that the author uses is quantitative research, namely research methods based on the philosophy of positivism, used to examine certain populations or samples, sampling techniques are generally carried out randomly, data collection uses research instruments, data analysis is quantitative/statistical with the aim of testing established hypothesis.

\section{Research Object}

In this study, the authors conducted research on UD. Ghoni Jati Jaya. Because UD. Ghoni Jati Jaya is one of the businesses engaged in the Jepara furniture trade industry. UD. Ghoni Jati Jaya is a business with prospects in the field of marketing. 
UD. Ghoni Jati Jaya is located in Miru-Maduran-Lamongan Village. The author takes the object of research at UD. Ghoni Jati Jaya Because he wants to observe and research about the marketing that is being done.

\section{Population}

According to Sugiono (2015) suggests that the population is a generation area consisting of objects or subjects that have certain qualities or characteristics determined by researchers to study and then draw conclusions. Based on these qualities and characteristics, the population can be understood as a group of individuals and objects of observation that have at least one characteristic in common. Consumers of UD Ghoni Jati Jaya are predicted to be 350 per year. It was taken from the time it was founded in 2014 to 2020 as many as 2450 consumers.

\section{Sample}

According to Sugiono (2015) the sample is part of the number and characteristics possessed by the population. If the population is large, and the research is not possible to study everything in the population, for example due to limited funds, manpower and time, the researcher can use samples taken from that population. What is learned from the sample, the conclusions can be applied to the population. For this reason, samples taken from the population must be truly representative (representative). This research was conducted by distributing questionnaires to consumers. Based on the sales of UD Ghoni Jati Jaya, it was taken for 3 years, namely from 2017 to 2019 as many as 30 consumers.

\section{Sampling Engineering}

According to Sugiono (2019) the sampling technique is a sampling technique. The sampling technique used in this study is probability sampling which provides equal opportunities for each element (member) of the population to be selected as a member of the sample. The technique used is the Simple Random Sampling technique. According to Sugiono (2015:119) the sampling technique is random sampling, which is the taking of sample members from the population at random without regard to the existing strata in the population.

\section{Data Collection Method}

To be able to collect complete data, this study used the following data collection techniques:

1. Observation.

2. Interview (Interview)

3. Questionnaire (Questionnaire)

Data analysis is a process of simplifying data into a form that is easier to read. By using quantitative methods, it is hoped that more accurate measurement results will be obtained about the responses made by respondents, so that data in the form of numbers can be processed using statistical methods. The tools to be used are as follows: 


\section{Testing Data Analysis}

1. Multiple Linear Regression

To determine the effect of the independent variable on the dependent variable. According to Sugiyono (2008:122) formulate multiple linear regression analysis as follows:

$$
\mathrm{Y}=\mathrm{a}+1 \mathrm{X} 1+2 \mathrm{X} 2+3 \mathrm{X} 3
$$

$\mathrm{Y}=$ Purchase decision.

$\mathrm{a}=$ Constant

$1=$ Multiple regression coefficient of independent variable X1 to variable $Y$, if variables X2 and X3 are considered constant.

2 = Multiple regression coefficient of independent variable X2 to variable $Y$, if variables $\mathrm{X} 1$ and $\mathrm{X} 3$ are considered constant.

3 = Multiple regression coefficient of independent variable X3 to variable $Y$, if variables $\mathrm{X} 1$ and $\mathrm{X} 2$ are considered constant.

$\mathrm{X} 1=$ Price which is the 1 st independent variable.

$\mathrm{X} 2$ = Product quality which is the 2 nd independent variable.

$\mathrm{X} 3=$ Quality of service which is the 3rd independent variable.

\section{RESULT AND DISCUSSION}

\section{Multiple Linear Regression Analysis}

To see the extent to which the influence and relationship of the variables of changes in price level, product quality, and service quality that affect purchasing decisions at UD. Ghoni Jati Jaya, then data processing will be carried out through multiple linear regression equations, where changes in price level (X1), product quality (X2), service quality (X3), on purchasing decisions (Y).

Table 1. Multiple Regression Coefficient Value

\begin{tabular}{|l|l|r|r|r|r|r|}
\hline \multirow{2}{*}{ Model } & \multicolumn{2}{|c|}{$\begin{array}{c}\text { Unstandardized } \\
\text { Coefficients }\end{array}$} & $\begin{array}{c}\text { Standardized } \\
\text { Coefficients }\end{array}$ & & \\
\cline { 2 - 7 } \multicolumn{2}{|c|}{} & \multicolumn{1}{|c|}{ B } & Std. Error & Beta & \multicolumn{1}{c|}{ T } & Sig. \\
\hline \multirow{3}{*}{1} & 8.815 & 4.702 & & 1.875 & .072 \\
\cline { 2 - 7 } & (Constant) & -.007 & .171 & -.008 & -.041 & .968 \\
\cline { 2 - 7 } & Price level change & .031 & .156 & .037 & .201 & .842 \\
\cline { 2 - 7 } & product quality & .472 & .232 & .373 & 2.041 & .052 \\
\hline
\end{tabular}

Primary data sources processed 2020

From table 4.11 above, the results obtained are entered in the following equation:

Multiple Regression Equation

$\mathrm{Y}=\mathrm{a}+\mathrm{b} 1 \mathrm{X} 1+\mathrm{b} 2 \mathrm{X} 2+\mathrm{b} 3 \mathrm{X} 3$

Where:

$\mathrm{Y}=$ Purchase Decision

$\mathrm{X} 1=$ Change in the price level

X2 = Product Quality 
X3 = Service Quality

$\mathrm{a}=$ Constant

$\mathrm{b}=$ Regression coefficient

$\mathrm{Y}=8.815+(-0.007) \mathrm{X} 1+0.031 \mathrm{X} 2+0.472 \mathrm{X} 3$

From the above equation, the regression coefficient obtained can be explained as follows:

a. The constant $\mathrm{a}=8.815$ means that if the variables of changes in price levels, product quality, and service quality are equal to zero or unchanged, then the $\mathrm{Y}$ value or purchase decision is 8.815 . Or it can be said that the three variables including changes in price levels, product quality, and service quality have a joint effect of about $88.1 \%$ on purchasing decisions.

b. The value of the coefficient of change in the price level for the $\mathrm{X} 1$ variable is 0.007 . This means that every decrease in the price level of one unit, the purchase decision will decrease by -0.007 or it can be said that changes in the price level have a negative effect of $0.7 \%$ on purchasing decisions.

c. The value of the product quality coefficient for the $\mathrm{X} 2$ variable is 0.031 . This means that for every one unit increase in product quality, the purchase decision will increase by 0.031 or it can be said that the product quality variable has an effect of $3.1 \%$ on purchasing decisions.

d. The value of the service quality coefficient for the $\mathrm{X} 3$ variable is 0.472 . This means that for every one unit increase in service quality, the purchasing decision will increase by 0.472 or it can be said that the service quality variable has an effect of $47.2 \%$ on purchasing decisions.

\section{CONCLUSION}

Based on the results of the research, the results of the analysis and discussion that have been put forward by the author on purchasing decisions at UD.Ghoni Jati Jaya in the previous chapters, conclusions can be drawn from the overall results of the analysis as follows:

1. Variable changes in price level, product quality, and service quality have a significant effect on purchasing decisions at UD.Ghoni Jati Jaya by $88.1 \%$.

2. Variable changes in price level (X1) have a negative effect on purchasing decisions at UD.Ghoni Jati Jaya by $0.7 \%$.

3. Product quality variable (X2) has a significant effect on purchasing decisions at UD.Ghoni Jati Jaya by $3.1 \%$.

4. Service quality variable (X3) has a significant effect on purchasing decisions at UD.Ghoni Jati Jaya by $47.2 \%$.

5. The purchasing decision variable has an effect on UD. Ghoni Jati Jaya $49.6 \%$ 


\section{ACKNOWLEDGMENTS}

The author thanks the leadership of the foundation who has financed and supported this research, to fellow lecturers and employees of the Islamic Economics High School, Permata Bojonegoro, for their invaluable advice.

\section{REFERENCES}

[1] Fajar Laksana (2008), Manajemen Pemasaran Pendekatan Praktis, Edisi Pertama, Graha Ilmu, Yogyakarta.

[2] Fifyanita Ghanimata, Mustafa Kamal, 2016. Jurnal, Analisis Pengaruh Harga, Kualitas Produk, dan Lokasi Terhadap Keputusan Pembelian (Studi pada Pembeli Produk Bandeng Juwana Elrina Semarang) Jurusan Manajemen Fakultas Ekonomika dan Bisnis Universitas Diponegoro.

[3] https://adamfirdaus46.wordpress.com/2019/05/27/akutansi-perubahan -harga-inflasi/

[4] Ika Putri Iswayanti, 2015. Skripsi, Analisis Pengaruh Kualitas Produk, Kualitas Layanan, Hara, Dan Tempat Terhadap Keputusan Pembelian pada rumah makan "Soto Angkring Mas Boed". Fakultas Ekonomika dan Bisnis Universitas Diponegoro Semarang.

[5] Kotler, philip \& Kevin Lare Keller. 2007. Manajemen pemasaran; Edisi Dua Belas Jilid 1. Alih Bahasa Benyamin Molan. Indeks. Jakarta.

[6] Kotler, Philip dan Gary, Armstrong. 2001. Prinsip-prinsip Pemasaran. Alih Bahasa Imam Nurmawan Jakarta : Erlangga.

[7] Kotler, Philip. 2005. Manajemen Pemasaran. Jilid II. Edisi Kesebelas. Alih Bahasa Benyamin Molan. Jakarta. : Indeks

[8] M. Rizwar Ghazali, 2015. Skripsi, Analisis pengaruh lokasi, promosi, dan kualitas layanan terhadap keputusan membeli (warnet (warung internet) XYZ J1. Singosari Semarang). Fakultas Ekonomika dan Bisnis Universitas Diponegoro Semarang.

[9] Nana Herdiana Abdurrahman (2019), Manajemen Strategi Pemasaran, Edisi Pertama, CV. Pustaka Setia, Bandung.

[10] Pride William M, dkk (2018), Pengantar Bisnis, edisi 11, Terjemahan oleh William Abdillah dan Dian Angelina, Salemba Empat Jakarta.

[11] Sugiyono., 2007. Metode Penelitian Bisnis (Pendekatan Kuantitatif, Kualitatif dan R\&D). Penerbit Alfabeta. Bandung.

[12] Sugiyono., 2015. Metode Penelitian Bisnis. Penerbit Alvabeta Bandung. Cetakan ke 15 Oktober 2015.

[13] Viens.blogspot.co.id/2017/01kualitas-produk.html diakses pada hari senin, 16 Mei 2020, Pukul 19.17 WIB. 